\title{
APLICATION OF TRADITIONAL GAMES DAKON (ATGD) SEBAGAI LANGKAH UNTUK MEMBENTUK NILAI KARAKTER PADA ANAK USIA DINI DI TK KREATIF PRIMAGAMA TERBAN
}

\author{
Oleh: \\ Sri Nuryanto \\ SMK Citra Medika Magelang
}

\begin{abstract}
Abstrak
Penelitian ini bertujuan untuk membentuk nilai karakter yang unggul pada anak usia dini di TK Kreatif Primagama Terban Yogyakarta. Metode penelitian yang digunakan dalam permainan tradisional ini yaitu dengan menggunakan Penelitian Tindakan Kelas sesuai dengan desain yang dikembangkan oleh Kemmis dan Taggart.

Hasil penelitian menunjukkan bahwa disaat siklus pertama siswa masih sulit untuk dikondisikan serta diarahkan, terdapat beberapa siswa yang mengalami kesulitan dalam bermain dakon, tim peneliti segera memberikan bimbingan dan pengarahan kepada siswa tersebut. Selain itu, terdapat beberapa siswa yang terlihat antusias dengan mengikuti jalannya permainan dakon. Pada siklus pertama para siswa asyik dengan dakonnya tersebut, hingga ada siswa yang tidak mau bergantian dengan lawan mainnya, ada yang menangis dan saling berebut isi dakon (congklak). Selanjutnya di siklus kedua dan ke tiga mengalami perubahan yang signifikan, siswa yang bersangkutan sudah bisa memahami nilai-nilai karakter misalnya nilai kesabaran, menghormati antar sesama, dan rasa peduli dengan karakter mereka yang masih anak-anak. Kemudian tim peneliti menambahkan penjelasan karakter yang mereka pahami tersebut dengan bahasa yang dapat mereka mengerti. Dengan adanya permainan tradisional dakon ini harapannya dapat diterapkan dalam media pembelajaran sekolah khususnya pada pendidikan anak usia dini.
\end{abstract}

Kata kunci: Permainan tradisional, Karakter, Siswa

\section{Pendahuluan}

Potensi karakter yang baik telah dimiliki olehsetiap manusia sebelum dilahirkan, tetapi potensi tersebut harus terus menerus dibina melalui sosialisasi dan pendidikan sejak usia dini. Karakter merupakan kualitas moral dan mental seseorang yang pembentukannya dipengaruhi oleh faktor bawaan (fitrah-natural) dan lingkungan (sosialisasi atau pendikan natural). Pendidikan merupakan salah satu wadah dalam menunjang pembentukan karakter tiap individu. Taman Kanak-Kanak (TK) merupakan pendidikan awal penanaman karakter anak dalam perkembangan dirinya. Tak dapat kita pungkiri bahwa banyaknya generasi di Indonesia, yang tidak mengenal dirinya sebagai bangsa Indonesia yang memiliki berbagai macam suku, budaya, 
dan kultur sosial yang berbeda.Meskipun semua pihak bertanggungjawab atas pendidikan karakter calon generasi penerus bangsa (anak-anak), namun keluarga merupakan wahana pertama dan utama bagi pendidikan karakter anak untuk membentuk karakter anak, keluarga harus memenuhi tiga syarat dasar bagi terbentuknya kepribadian yang baik, yaitumaternal bonding, rasa aman, stimulasi fisik dan mental. Selain itu, jenis pola asuh yang diterapkan orang tua kepada anaknya juga menentukan keberhasilan pendidikan karakter anak di rumah. Kesalahan dalam pengasuhan anak di keluarga akan berakibat pada kegagalan dalam pembentukan karakter yang baik.

Namun bagi sebagian keluarga, proses pendidikan karakter yang sistematis di atas sangat sulit, terutama bagi sebagian orang tua yang terjebak pada rutinitas yang padat. Karena itu, seyogyanya pendidikan karakter juga perlu diberikan pada saat anak-anak masuk dalam lingkungan sekolah, terutama sejak play group dan taman kanak-kanak. Di sinilah peran guru, yang dalam filosofi Jawa disebut digugu lan ditiru (didengar dan dicontoh), dipertaruhkan. Karena guru adalah ujung tombak di kelas, yang berhadapan langsung dengan peserta didik. Taman Kanak-Kanak dan sejenisnya merupakan tempat atau pun taman bermain untuk membentuk serta merangsang pola pikir kreatifitas anak, bukan sepenuhnya tempat untuk belajar. Oleh karena itu, penanaman pendidikan karakter pada tingkat tersebut tidak mendapat porsi yang besar (Nuh, Muhammad. 2010).

Dewasa ini hampir sebagian besar di Taman Kanak-Kanak (TK) para siswa dalam memperoleh pendidikan karakter masih terdapat melalui metode ceramah serta nasihat-nasihat singkat, sehingga anak kurang mampu memahami tentang nilai pendidikan karakter yang baik serta bersifat mendidik. Melihat permasalahan tersebut, bahwa penanaman serta pembentukan nilai-nilai pendidikan karakter pada anak TK dapat disampaikan dengan cara yang lebih menarik, efektif serta menyenangkan, yaitu dengan menggunakan permainan tradisional melalui media dakon. Fokus dari permainan tradisional dakon ini yaitu pada permainan yang didalamnya sudah mengandung nilai-nilai pendidikan karakter, nilai karakter yang terkandung di dalamnya misalnya melatih kejujuran, kesabaran dan peduli dengan sesama, permainan tradisional dengan menggunakan media dakon ini menjadikan anak tidak merasa tertekan dan terbebani dengan berbagai konsep maupun teori. Maka dari itu, penelitian ini difokuskan pada pemberian pemahaman nilai-nilai pendidikan karakter dengan permainan tradisional yang harapannya 
mampu meningkatkan, merangsang kemampuan anak dari mulai aspek kognitif, afektif dan psikomotorik untuk membina serta membentuk karakter siswa yang lebih baik serta lebih bersifat mendidik. Berdasarkan pemikiran dan pertimbangan tersebut maka diperlukan suatu penelitian lebih lanjut untuk menemukan suatu bentuk atau pun cara yang strategis dan menarik para siswa yang diharapkan mampu menanamkan serta membina pendidikan karakter pada anak sejak dini yaitu dengan Application ofTraditional GamesDakon (ATGD) Sebagai Langkah Untuk Membentuk Nilai Karakter Pada Anak Usia Dini di TK Kreatif Primagama Terban Yogyakarta.

\section{Pendidikan Karakter}

Karakter dapat dianggap sebagai nilai-nilai perilaku manusia yang berhubungan dengan Tuhan Yang Maha Esa, diri sendiri, sesama manusia, lingkungan, dan kebangsaan yang terwujud dalam pikiran, sikap, perasaan, perkataan, perbuatan berdasarkan norma-norma agama, hukum, tata karma, budaya, adat istiadat dan estetika. Karakter adalah perilaku yang tampak dalam kehidupan sehari-hari baik dalam bersikap maupun dalam bertindak. Warsono dkk. (2010) mengutip Jack Corley dan Thomas Phillip (2000) menyatakan : Karakter merupakan sikap dan kebiasaan seseorang yang memungkinkan dan mempermudah tindakan moral. Berdasarkan grand design yang dikembangkan Kemendiknas (2010), secara psikologis dan sosial kultural pembentukan karakter dalam diri individu merupakan fungsi dari seluruh potensi individu manusia (kognitif, afektif, dan psikomotorik) dalam konteks interaksi sosial kultural (dalam keluarga, sekolah, dan masyarakat) dan berlangsung sepanjang hayat.

Berdasarkan pembahasan di atas dapat ditegaskan bahwa pendidikan karakter merupakan upaya-upaya yang dirancang dan dilaksanakan secara sistematis untuk membantu peserta didik memahami nilai-nilai perilaku manusia yang berhubungan dengan Tuhan Yang Maha Esa, diri sendiri, sesama manusia, lingkungan, dan kebangsaan yang terwujud dalam pikiran, sikap, perasaan, perkataan, dan perbuatan berdasarkan norma-norma agama, hukum, tata krama, budaya, dan adat istiadat. 


\section{Nilai Pendidikan Karakter}

Ada 18 nilai-nilai dalam pengembangan pendidikan karakter bangsa yang dibuat oleh Diknas. Mulai tahun ajaran 2011, seluruh tingkat pendidikan di Indonesia harus menyisipkan pendidikan berkarakter tersebut dalam proses pendidikannya. 18 nilai-nilai dalam pendidikan karakter menurut Diknas adalah:

1. Religius, Sikap dan perilaku yang patuh dalam melaksanakan ajaran agama yang dianutnya, toleran terhadap pelaksanaan ibadah agama lain, dan hidup rukun dengan pemeluk agama lain.

2. Jujur, Perilaku yang didasarkan pada upaya menjadikan dirinya sebagai orang yang selalu dapat dipercaya dalam perkataan, tindakan, dan pekerjaan.

3. Toleransi, Sikap dan tindakan yang menghargai perbedaan agama, suku, etnis, pendapat, sikap, dan tindakan orang lain yang berbeda dari dirinya.

4. Disiplin, Tindakan yang menunjukkan perilaku tertib dan patuh pada berbagai ketentuan dan peraturan.

5. Kerja Keras, Tindakan yang menunjukkan perilaku tertib dan patuh pada berbagai ketentuan dan peraturan.

6. Kreatif, Berpikir dan melakukan sesuatu untuk menghasilkan cara atau hasil baru dari sesuatu yang telah dimiliki.

7. Mandiri, Sikap dan perilaku yang tidak mudah tergantung pada orang lain dalam menyelesaikan tugas-tugas.

8. Demokratis, Cara berfikir, bersikap, dan bertindak yang menilai sama hak dan kewajiban dirinya dan orang lain.

9. Rasa Ingin Tahu, Sikap dan tindakan yang selalu berupaya untuk mengetahui lebih mendalam dan meluas dari sesuatu yang dipelajarinya, dilihat, dan didengar.

10. Semangat Kebangsaan, Cara berpikir, bertindak, dan berwawasan yang menempatkan kepentingan bangsa dan negara di atas kepentingan diri dan kelompoknya.

11. Cinta Tanah Air, Cara berpikir, bertindak, dan berwawasan yang menempatkan kepentingan bangsa dan negara di atas kepentingan diri dan kelompoknya. 
12. Menghargai Prestasi, Sikap dan tindakan yang mendorong dirinya untuk menghasilkan sesuatu yang berguna bagi masyarakat, dan mengakui, serta menghormati keberhasilan orang lain.

13. Bersahabat/Komunikatif, Sikap dan tindakan yang mendorong dirinya untuk menghasilkan sesuatu yang berguna bagi masyarakat, dan mengakui, serta menghormati keberhasilan orang lain.

14. Cinta Damai, Sikap dan tindakan yang mendorong dirinya untuk menghasilkan sesuatu yang berguna bagi masyarakat, dan mengakui, serta menghormati keberhasilan orang lain.

15. Gemar Membaca, Kebiasaan menyediakan waktu untuk membaca berbagai bacaan yang memberikan kebajikan bagi dirinya.

16. Peduli Lingkungan, Sikap dan tindakan yang selalu berupaya mencegah kerusakan pada lingkungan alam di sekitarnya, dan mengembangkan upaya-upaya untuk memperbaiki kerusakan alam yang sudah terjadi.

17. Peduli Sosial, Sikap dan tindakan yang selalu ingin memberi bantuan pada orang lain dan masyarakat yang membutuhkan.

18. Tanggung Jawab, Sikap dan perilaku seseorang untuk melaksanakan tugas dan kewajibannya, yang seharusnya dia lakukan, terhadap diri sendiri, masyarakat, lingkungan (alam, sosial dan budaya), negara dan Tuhan Yang Maha Esa.

Suyanto via Suparlan dalam www.suparlan.com menyebutkan ada sembilan pilar karakter berasal dari nilai-nilai luhur universal manusia. Sembilan pilar karakter itu adalah cinta Tuhan dan segenap ciptaan-Nya, kemandirian dan tanggungjawab, kejujuran atau amanah, hormat dan santun, dermawan, suka tolong menolong dan gotong royong atau kerjasama, percaya diri dan pekerja keras, kepemimpinan dan keadilan, baik dan rendah hati, toleransi, kedamaian, dan kesatuan.

\section{Permainan Tradisional dengan menggunakan dakon}

Permainan tradisional merupakan simbolisasi dari pengetahuan yang turun temurun dan mempunyai bermacam-macam fungsi atau pesan di baliknya, di mana pada prinsipnya permainan anak tetap merupakan permainan anak. Dengan demikian bentuk atau wujudnya tetap menyenangkan dan menggembirakan anak karena tujuannya sebagai media permainan. Aktivitas permainan yang dapat mengembangkan aspek-aspek psikologis anak dapat dijadikan sarana 
belajar sebagai persiapan menuju dunia orang dewasa. Permainan digunakan sebagai istilah luas yang mencakup jangkauan kegiatan dan perilaku yang luas serta mungkin bertindak sebagai ragam tujuan yang sesuai dengan usia anak.

Menurut Mulyadi (2004: 30) bermain secara umum sering dikaitkan dengan kegiatan anak-anak yang dilakukan secara spontan yang terdapat lima pengertian bermain; (1) sesuatu yang menyenangkan dan memiliki nilai intrinsik pada anak (2) tidak memiliki tujuan ekstrinsik, motivasinya lebih bersifat intrinsik (3) bersifat spontan dan sukarela, tidak ada unsur keterpaksaan dan bebas dipilih oleh anak serta melibatkan peran aktif keikutsertaan anak, dan (4) memiliki hubungan sistematik yang khusus dengan suatu yang bukan bermain, seperti kreativitas, pemecahan masalah, belajar bahasa, perkembangan sosial.Oleh karena itu, bahwa permainan tradisional disini adalah permainan anak-anak dari bahan sederhana sesuai aspek budaya dalam kehidupan masyarakat. Permainan tradisional juga dikenal sebagai permainan rakyat merupakan sebuah kegiatan rekreatif yang tidak hanya bertujuan untuk menghibur diri, tetapi juga sebagai alat untuk memelihara hubungan dan kenyamanan sosial. Dengan demikian bermain suatu kebutuhan bagi anak. Jadi bermain bagi anak mempunyai nilai dan ciri yang penting dalam kemajuan perkembangan kehidupan sehari-hari termasuk dalam permainan tradisional (Cony Semiawan. 2008: 22).

Menurut Bennet (1998:46) dengan ini diharapkan bahwa permainan dalam pendidikan untuk anak usia dini ataupun anak sekolah terdapat pandangan yang jelas tentang kualitas belajar, hal ini diindikasikan sebagai berikut: (1) gagasan dan minat anak merupakan sesuatu yang utama dalam permainan, (2) permainan menyediakan kondisi yang ideal untuk mempelajari dan meningkatkan mutu pembelajaran, (3) rasa memiliki merupakan hal yang pokok bagi pembelajaran yang diperoleh melalui permainan, (4) anak akan mempelajari cara belajar dengan permainan serta cara mengingat pelajaran dengan baik, (5) pembelajaran dengan permainan terjadi dengan mudah, tanpa ketakutan, (6) permainan memudahkan para guru untuk mengamati pembelajaran yang sesungguhnya dan siswa akan mengalami berkurangnya frustasi belajar.

Permainan Tradisional untuk membentuk pendidikan karakter anak pada usia dini khususnya di Taman Kanak-Kanak ini dengan memperkenalkan jenis permainan tradisional dengan menggunakan dakon. Menurut (http : //safawi.multiply.com/2007) Wikipedia Indonesia, dakon atau sering dinamakan cangklok dikenal dengan berbagai macam nama di seluruh 
Indonesia. Sejenis cangkang kerang biasanya digunakan sebagai congklak dalam permainan. Dalam permainan tradisional dakon ini seorang pemain dakon atau congklak yang mahir tentunya memiliki kekuatan dalam berhitung dan memilih peluang akan pembagian biji-biji ke dalam masing-masing cekungan yang terdapat dalam alat bermainnya. Permainan ini dilakukan oleh dua orang. Aturan permainannya beragam, namun yang biasa dimainkan satu pemain hanya memiliki satu lumbung dan harus diisi dalam setiap kali berputar. Permainan diawali secara bersamaan, dan setiap lubang selalu diisi kecuali lumbung lawan. Jika pada biji terakhir masih ada biji di dalam lubang permainan dapat dilanjutkan hingga jatuh pada lubang yang kosong. Jika biji jatuh pada lubang di daerah kekuasaan dan pada daerah diseberang lawan ada biji lainnya, si pemain dapat mengambil semua biji tersebut dan menaruhnya pada lumbung. Dan permainan terus berulang seperti diatas. Permainan dibagi menjadi beberapa kelompok dengan tujuan untuk melatih dan memberikan pemahaman anak dalam bermain bersama, harus selalu menghormati satu sama lain, serta melatih kejujuran dan kesabaran menunggu giliran untuk memainkan biji dakonnya, selain itu dalam permainan ini siswa dilatih dalam hal berhitung (kecerdasan) sehingga akan membentuk dan melatih siswa dalam pendidikan karakter yang unggul.

\section{Metode Penelitian}

\section{a. Desain Penelitian}

Penelitian ini dilaksanakan untuk mengetahui penerapan permainan tradisional dengan menggunakan dakon untuk membentuk nilai karakter anak pada usia dini di TK Kreatif Primagama Yogyakarta. Penelitian ini merupakan Penelitian tindakan kelas (classroom action research). Penelitian tindakan kelasadalah ragam penelitian pembelajaran yang berkonteks kelas untuk memecahkan masalah-masalah pembelajaran dalam kelas.

Empat tahapan dalam penelitian tindakan kelas menurut Kemmis dan Mc. Taggart (Suwarsih Madya, 2007: 59-64).

1. Perencanaan (planning)

Rencana penelitian tindakan merupakan tindakan yang tersusun dan dari segi definisi harus mengarah pada tindakan yaitu bahwa itu harus memandang kedepan.

2. Pelaksanaan tindakan (action) 
Tindakan yng dimaksud disini adalah tindakan yang secara sadar dan terkendali yang merupakan variasi praktik yang cermat dan bijaksana, jadi tindakan itu mengandung inovasi atau pembaharuan, betapapun kecilnya yang berada dengan yang bisa dilakukan sebelumnya.

3. Pengamatan (observasion)

Observasi berfungsi untuk mendokumentasikan pengaruh tindakan terkait bersama prosesnya. Observasi itu berorientasi ke masa yang akan datang, memberikan dasar bagi refleksi, lebih-lebih lagi ketika siklus terkait masih berlangsung. Rencana observasi harus fleksibel dan terbuka untuk mencatat hal-hal yang tak terduga.

4. Refleksi (reflection)

Refleksi adalah mengingat dan merenungkan kembali suatu tindakan persis seperti yang telah dicatat dalam obsevasi. Refleksi berusaha memahami proses, masalah, persoalan, dan kendala yang nyata dalam tindakan strategi. Strategi memiliki aspek evaluative yaitu meminta peneliti tindakan untuk menimbang-nimbang pengalamanya, untuk menilai apakah (persoalan yang timbul) memang diinginkan dan memberikan saran-saran tentang cara-cara untuk meneruskan pekerjaan.

\section{b. Setting Penelitian}

1. Tempat dan Waktu Penelitian

Penelitian ini akan dilaksanakan di TK Kreatif Primagama Yogyakarta. Pada bulan Juni sampai Juli 2013.

2. Subjek Penelitian

Subjek Penelitian yaitu siswa kelas B.3 di TK Kreatif Primagama Yogyakarta sejumlah 12 orang. Objek penelitiannya yaitu nilai-nilai pendidikan karakter.

3. Teknik Pengumpulan Data

Adapun teknik pengumpulan data yang digunakan dalam penelitian ini yaitu dengan menggunakan observasi. Observasi dilakukan dengan tujuan untuk mengetahui hasil belajar siswa. Selain itu, observasi juga dilakukan untuk mengamati secara langsung proses pembelajaran berdasarkan pedoman observasi yang telah disusun. Hal-hal yang ditemukan dalam penelitian tetapi tidak terdapat dalam pedoman observasi dimasukan dalam catatan 
lapangan. Dalam kegiatan ini dipersiapkan lembar observasi yang terdiri dari observasi kegiatan awal, kegiatan inti dan kegiatan akhir.

4. Instrumen Penelitian

Instrumen penelitian yang digunakan peneliti dalam pengambilan data adalah dengan menggunakan lembar observasiuntuk mencatat tingkah laku siswa, peristiwa, kegiatan pembelajaran dan semua kondisi yang menyangkut penelitian.

5. Teknik Analisis Data

Langkah-langkah analisis data yang akan digunakan dalam penelitian ini adalah :

a. Reduksi data adalah proses penyederhanaan yang dilakukan melalui seleksi, pemfokusan, dan pengabstraksian data mentah menjadi informasi yang bermakna.

b. Paparan data adalah proses penampilan data secara lebih sederhana dalam bentuk paparan naratif, representasi tabular termasuk dalam format matriks, grafis, dan sebagainya.

c. Penyimpulan adalah proses pengambilan intisari dari sajian data yang telah terorganisir tersebut dalam bentuk pernyataan kalimat.

\section{Hasil Penelitian dan Pembahasan}

\section{A. Deskripsi Hasil Penelitian}

Pada dasarnya penelitian ini bertujuan untuk memperoleh gambaran kualitas proses pembelajaran siswa dengan menggunakan dan mengimplementasikan permainan tradisional dengan media dakon sebagai langkah untuk membentuk nilai karakter pada anak usia dini. Kualitas proses pembelajaran dalam penelitian ini akan tergambar dari: (1) keterampilan mengajar peneliti dalam proses pembelajaran, (2) aktivitas siswa dan peneliti selama pembelajaran berlangsung, (3) respon siswa dalam pembelajaran menggunakan media dakon untuk membentuk nilai karakter. Sedangkan kualitas hasil pembelajaran akan tergambar dari hasil permainan tradisional dengan menggunakan dakon berupa pemahaman nilai-nilai karakter pada siswa yaitu bersikap jujur, sikap peduli, sabar serta menghormati antar sesama.

\section{B. Pembahasan dan Analisis}

Hasil penelitian ini merupakan gambaran secara utuh dan menyeluruh dari penelitian yang berjudul "Application of Traditional Games Dakon (ATGD) sebagai langkah membentuk 
nilai karakter pada anak usia dini di TK Kreatif Primagama Yogyakarta. Pada saat tim peneliti observasi ke TK Kreatif di Terban Yogyakarta, melakukan wawancara kepada ibu nana selaku manajer di TK Kreatif Primagama, pembelajaran pendidikan karakter di kelas B.2 masih kurang maksimal dan suasananya kurang kondusif, siswa terlihat masih sulit untuk dikondisikan, siswa masih sering bertengkar. Selain kondisi dari siswa, dari pihak guru belum melakukan pembelajaran yang bersifat inovatif, siswa hanya diberikan nasehat secara lisan, jadi siswa cenderung bersifat acuh dan kurang menerima penjelasan dari pihak guru. Melihat kondisi tersebut, penulis sekaligus peneliti mencoba memberikan solusi yang kreatif dan inovatif berupa media pembelajaran inovatif yang berupa permainan tradisional yang menekankan pada media dakon sebagai langkah awal untuk membentuk nilai karakter anak di TK Kreatif Yogyakarta kelas B.2. Adapun Nilai-nilai karakter tersebut yaitu jujur, kerjasama, cerdas, peduli, kreatif dan keberanian.

\section{Perencanaan}

Pada tahap perencanaan, tim peneliti mengkonsep serta merancang kegiatan pembelajaran pada setiap siklusnya dengan menentukan jenis permainan tradisional serta bagaimana cara memainkannya. Selain itu menentukan nilai-nilai pendidikan karakter yang terkandung di dalamnya yang memuat alokasi waktu, persiapan sampai teknis pelaksanaannya.

\section{Pelaksanaan}

\section{Siklus I}

Pada siklus pertama, tim peneliti memberikan permainan tradisional dengan menggunakan media dakon, yang dilaksanakan pada hari kamis tanggal 21 Juni 2012. Pada siklus pertama ini dilaksanakan selama 60 menit, yaitu dari Pk. 09.00-10.00 wib, dengan alokasi waktu 15 menit pertama pembukaan yaitu dengan pengkondisian, perkenalan, dilanjutkan menyanyi sebagai pemberian semangat serta motivasi kepada para siswa, 35 menit dengan permainan, serta 15 menit untuk refleksi dan penutupan. Subjek penelitian pada siklus pertama berjumlah 10 siswa. Dalam pelaksanaannya para siswa merespon dan memberikan tanggapan dengan serius serta mudah mengikuti instruksi dan pengarahan dari tim peneliti. Penelitian ini 
diawali dengan perkenalan kelompok peneliti oleh ibu Mia selaku guru kelas B.2. Selanjutnya tim peneliti memperkenalkan sekaligus memberikan penjelasan permainan tradisional dengan menggunakan dakon. Kemudian Tim peneliti memberikan penjelasan kepada siswa tentang bagaimana cara bermain dakon dengan baik dan benar. Siswa dibagi ke dalam beberapa kelompok kecil. Tiap kelompok terdiri atas 2 orang. Jadi dalam permainan dakon ini terdapat 5 kelompok. Dari analisis permasalahan tersebut, siswa yang bersangkutan belum memahami nilainilai karakter misalnya nilai kesabaran, menghormati antar sesama, dan rasa peduli. Kemudian tim peneliti melakukan pendekatan secara personal untuk memberikan penjelasan serta pemahaman nilai-nilai karakter tersebut.

Setelah permainan dakon, siswa di bimbing serta diarahkan untuk diajak berdialog tentang apa saja yang diperoleh setelah bermain dakon. Ada beberapa siswa yang memahami mengenai nilai-nilai karakter, ada juga siswa yang kurang memahami tentang nilai-nilai karakter.

\section{Pengamatan}

Pengamatan ini dilakukan untuk mengetahui antusiasme siswa dalam mengikuti permainan tradisional dengan menggunakan media dakon, selain itu juga untuk mengetahui pemahaman sikap/ nilai-nilai karakter anak. Misalnya sabar, peduli, kerjasama, keberanian dsb.

\section{Refleksi}

Permainan tradisional dengan menggunakan dakon berlangsung dengan 5 papan dakon. Siswa bermain secara bergiliran. Dari tim peneliti mengalami beberapa kendala atau kesulitan dalam memberikan pemahaman akan nilai kesabaran serta kepedulian karena beberapa siswa asyik dengan dakonnya tanpa mau memberikan kesempatan dengan temennya dalam bermain dakonnya. Selain itu, para siswa masih sulit untuk diarahkan dan dikondisikan. melihat permasalahan diatas, dalam melakukan siklus selanjutnya tim peneliti akan berusaha untuk lebih memberikan pengarahan dan bimbingan kepada siswa secara maksimal.

\section{Siklus II}

Pada siklus kedua, dilaksanakan pada hari kamis tanggal 28 Juni 2012. Pada siklus kedua ini dilaksanakan selama 60 menit, yaitu dari Pk. 09.00-10.00 wib, dengan alokasi waktu 10 menit pertama pembukaan yaitu dengan pengkondisian, perkenalan, dilanjutkan menyanyi sebagai pemberian semangat serta motivasi kepada para siswa, 40 menit dengan permainan, serta 10 menit untuk refleksi dan penutupan. Subjek penelitian pada siklus kedua berjumlah 10 siswa. 
Dalam pelaksanaannya para siswa merespon dan memberikan tanggapan dengan serius serta mudah mengikuti instruksi dan pengarahan dari tim peneliti. Siswa dibagi ke dalam beberapa kelompok kecil. Tiap kelompok terdiri atas 2 orang. Jadi dalam permainan dakon ini terdapat 5 kelompok. Dalam siklus kedua ini, siswa sudah mulai ada sedikit peningkatan yaitu siswa sudah mulai bisa diarahkan dan di kondisikan meskipun ada salah satu siswa yang mengalami sedikit kesulitan dalam bermain dakon, tim peneliti segera memberikan bimbingan dan pengarahan kepada siswa tersebut. Selain itu, Dari analisis permasalahan tersebut, siswa yang bersangkutan sudah sedikit bisa memahami nilai-nilai karakter misalnya nilai kesabaran, menghormati antar sesama, dan rasa peduli. Meskipun dalam tingkat memahaminya belum terlihat secara maksimal. Kemudian tim peneliti melakukan pendekatan secara personal untuk memberikan penjelasan serta pemahaman nilai-nilai karakter tersebut.

Setelah permainan dakon, siswa di bimbing serta diarahkan untuk diajak berdialog tentang apa saja yang diperoleh setelah bermain dakon. Sudah terlihat beberapa siswa yang sudah memahami nilai-nilai karakter. Hal ini terbukti sudah ada peningkatan jika dibandingkan dengan siklus yang pertama.

\section{Pengamatan}

Pengamatan ini dilakukan untuk mengetahui sejauh mana peningkatan kegiatan permainan dakon berlangsung dengan menggunakan media dakon selama siklus pertama ke siklus yang ke dua, selain itu juga untuk mengetahui pemahaman sikap dan nilai-nilai karakter anak. Misalnya sabar, peduli, kerjasama, keberanian dsb.

\section{Refleksi}

Permainan tradisional dengan menggunakan dakon berlangsung dengan 5 papan dakon. Siswa bermain secara bergiliran. Dari tim peneliti hanya mengalami sedikit kendala atau kesulitan dalam memberikan pemahaman akan nilai kesabaran serta kepedulian karena terlihat hanya sedikit siswa yang mengalami kesulitan, misalnya siswa kurang bisa memainkan biji dakon dengan cermat dan cepat, melihat analisis permasalahan tersebut, dalam melakukan siklus selanjutnya tim peneliti akan berusaha untuk lebih memberikan pengarahan dan bimbingan kepada siswa secara maksimal. 


\section{Siklus III}

Pada siklus ketiga, dilaksanakan pada hari kamis tanggal 29 Juni 2012. Pada siklus ketiga ini dilaksanakan selama 60 menit, yaitu dari Pk. 09.00-10.00 wib, dengan alokasi waktu 15 menit pertama pembukaan yaitu dengan pengkondisian, perkenalan, dilanjutkan menyanyi sebagai pemberian semangat serta motivasi kepada para siswa bertujuan agar siswa tidak mengalami kejenuhan, 35 menit dengan permainan, serta 10 menit untuk refleksi dan penutupan. Subjek penelitian pada siklus ketiga berjumlah 10 siswa. Dalam pelaksanaannya para siswa merespon dan memberikan tanggapan dengan serius serta mudah mengikuti instruksi dan pengarahan dari tim peneliti. Siswa dibagi ke dalam beberapa kelompok kecil. Tiap kelompok terdiri atas 2 orang. Jadi dalam permainan dakon ini terdapat 5 kelompok. Kemudian tim peneliti menambahkan penjelasan karakter yang mereka pahami tersebut dengan bahasa yang dapat mereka mengerti.

Setelah permainan dakon, seperti pertemuan-pertemuan sebelumnya siswa di bimbing serta diarahkan untuk diajak berdialog tentang apa saja yang diperoleh setelah bermain dakon. Sudah terlihat semua siswa sudah memahami nilai-nilai karakter. Hal ini terbukti sudah ada peningkatan yang signifikan jika dibandingkan dengan siklus yang pertama dan kedua.

\section{Pengamatan}

Pengamatan ini dilakukan untuk mengetahui sejauh mana peningkatan kegiatan permainan dakon berlangsung dengan menggunakan media dakon selama siklus pertama ke siklus kedua, dan siklus ketiga. Selain itu juga untuk mengetahui pemahaman sikap dan nilainilai karakter anak. Misalnya sabar, peduli, kerjasama, keberanian dsb.

\section{Refleksi}

Permainan tradisional dengan menggunakan dakon berlangsung dengan 5 papan dakon. Tim peneliti tidak mengalami kendala karena para siswa sudah paham dan mudah untuk diarahkan. Pada siklus yang ketiga ini siswa telah dapat bermain dakon sebagaimana yang diharapkan oleh Tim peneliti dan terlihat dengan jelas karakter yang diperlihatkan oleh para siswa yang telah sesuai dengan harapan. 


\section{Kesimpulan dan Saran}

\section{A. Kesimpulan}

Dari hasil penelitian yang dilakukan dapat diperoleh kesimpulan sebagai berikut:

Permainan Tradisional dengan menggunakan media dakon merupakan simbolisasi dari pengetahuan yang turun temurun dan mempunyai bermacam-macam fungsi atau pesan di baliknya, permainan tradisional anak merupakan permainan yangmenyenangkan dan menggembirakan. Selain itu juga dapat mengembangkan nilai-nilai karakter anak terutama pada aspek-aspek psikologis sebagai sarana belajar persiapan menuju dunia orang dewasa.

\section{B. Saran}

1. Hendaknya permainan tradisional dakon ini diterapkan mulsi pada anak usia dini sebagai pembentukan karakter yang unggul.

2. Adanya permainan tradisional dakon ini harapannya dapat diterapkan dalam media pembelajaran sekolah khususnya pada pendidikan anak usia dini

3. Guru dituntut supaya lebih aktif, kreatif, dan inovatif dalam membelajarkan permainan tradisional dakon ini sehingga siswa yang masih berusia dini tidak mengalami kebosanan dan dapat menerima esensi yang disalurkan serta anak semakin termotivasi oleh adanya pembelajaran dengan menggunakan media pembelajaran permainan tradisonal dakon tersebut. 


\section{Daftar Pustaka}

Bahan Pelatihan Penguatan Metodologi Pembelajaran Berdasarkan Nilai-nilai Budaya untuk Membentuk Daya Saing dan Karakter Bangsa, oleh Pusat Kurikulum Departemen Pendidikan Nasional, 2010.

Bennett, Neville. (2005). Teaching through play teachers thinking and classroom practice.(Terjemahan Nur Adi Trastria) USA: Open University press. (Buku asli diterjemahkan 1998)

Cony Semiawan. (2008). Belajar dan pembelajaran pra Sekolah da Sekolah dasar. Jakarta: Indeks

Kemendiknas. 2010. Pembinaan Pendidikan Karakter di Sekolah Menengah Pertama . Jakarta

Nuh, Muhammad. 2010. Pentingnya Kejujuran dan Pendidikan Karakter dalam Membangun Bangsa. http://m.antaranews.com (diakses pada tanggal 16 April 2012 Pk. 21.30 wib)

Mulyadi, S. (2004). Bermain dan kreativitas (Upaya Mengembangkan kreativitas anak melalui Kegiatan Bermain). Jakarta: Papas Sinar Sinanti .

Suparlan. 2010. Pendidikan Karakter dan Kecerdasan. http://www.suparlan.com/pages/posts/pendidikan-karakter-dan-kecerdasan-288.php. (diakses pada tanggal 16 April 2012 Pk. 21.00 wib).

Suwarsih Madya. 2007. Teori Praktik Penelitian Tindakan. Bandung: Alfabeta

Warsono, dkk, 2010. Model Pendidikan Karakter di Universitas negeri Surabaya, Surabaya : Unesa.

http://safawi.multiply.com/ 2007. Wikipedia Indonesia (diakses pada tanggal 16 April 2012 Pk. $22.00 \mathrm{wib})$ 